\title{
PILIHAN DAN SIKAP BAHASA MASYARAKAT DI PERBATASAN INDONESIA DAN TIMOR LESTE
}

\author{
Community Language Choice and Attitudes in the Border of Indonesia and Timor Leste
}

\author{
Mukhamdanah ${ }^{1}$, Retno Handayani ${ }^{2}$ \\ ${ }^{1,2}$ Badan Pengembangan dan Pembinaan Bahasa \\ retno.hdyn@gmail.com
}

Naskah Diterima Tanggal 12 September 2019_Direvisi Akhir Tanggal 20 Agustus 2020_Disetujui Tanggal 24 Oktober 2020 doi: https://doi.org/10.26499/rnh.v9i2.2923

\begin{abstract}
Abstrak
Masyarakat perbatasan yang berada di Kabupaten Malaka, Nusa Tenggara Timur terdiri atas dua kelompok masyarakat, yaitu kelompok masyarakat asli yang telah lama menetap dan kelompok masyarakat yang memilih bergabung ke dalam Negara Kesatuan Republik Indonesia. Adanya kontak sosial oleh masyarakat yang menetap di wilayah perbatasan tentunya menyebabkan terjadinya kontak bahasa yang memungkinkan mereka untuk memilih suatu bahasa dalam berkomunikasi. Tujuan penelitian ini adalah mengetahui kecenderungan pilihan dan sikap bahasa masyarakat perbatasan Indonesia-Timor Leste, yaitu bahasa apa yang aktif digunakan oleh masyarakat perbatasan dan bagaimana sikap bahasa masyarakat terhadap bahasa daerah, bahasa Indonesia, bahasa asing, dan bahasa negara tetangga. Penelitian ini menggunakan metode penelitian kuantitatif dan kualitatif. Analisis data pada penggunaan bahasa dikaitkan dengan pilihan bahasa oleh masyarakat. Suatu bahasa yang aktif digunakan menandakan bahwa bahasa itu dipilih oleh penutur. Hasil penelitian menunjukkan bahwa bahasa Indonesia menjadi bahasa yang dipilih dan paling aktif digunakan di wilayah perbatasan. Sementara itu, sikap bahasa masyarakat perbatasan terhadap bahasa Indonesia masih sangat positif dibandingkan dengan bahasa daerah, bahasa asing, dan bahasa negara tetangga.
\end{abstract}

Kata-kata kunci: kontak bahasa, pilihan bahasa, sikap bahasa.

\begin{abstract}
The border community in Malacca Regency, East Nusa Tenggara consists of two groups of people, namely indigenous groups who have lived for a long time and groups of people who choose to join the Unitary State of the Republic of Indonesia. The existence of social contact by people who live in border areas certainly leads to language contact which allows them to choose a language to communicate. The purpose of this study was to determine the tendency of language choices and attitudes of the Indonesia-Timor Leste border communities, namely what languages are actively used by border communities and how the attitudes of the community's language towards regional languages, Indonesian, foreign languages, and languages of neighboring countries. This research uses quantitative and qualitative research methods. Data analysis on language use was associated with language choice by the community. A language that is actively used indicates that the language is chosen by the speaker. The results show that Indonesian is the language chosen and most actively used in border areas. Meanwhile, the language attitude of the border community towards Indonesian is still very positive compared to regional languages, foreign languages, and languages of neighboring countries.
\end{abstract}

Keywords: language contact, language choice, language attitudes.

How to Cite: Mukhamdanah dan Retno Handayani. (2020). Pilihan dan Sikap Bahasa Masyarakat di Perbatasan Indonesia dan Timor Leste. Ranah: Jurnal Kajian Bahasa. 9(2). 326-340. doi: https://doi.org/10.26499/rnh.v9i2.2923 


\section{PENDAHULUAN}

Timor Leste yang pernah menjadi provinsi ke-27 di NKRI memilih berpisah dari Indonesia berdasarkan jajak pendapat yang dilaksanakan pada 30 Agustus 1999 di bawah pengawasan United Nation Mission in East Timor (UNAMET). Sebanyak 344.580 rakyat Timor Leste yang mewakili 78,5 persen dari total pemilih menentukan pilihan sebagai negara merdeka. Hanya 21,5 persen suara yang mewakili 94.388 rakyat Timor Leste menerima opsi otonomi luas yang ditawarkan oleh Presiden Republik Indonesia B.J. Habibie saat itu (Sudika, 2019).

Walaupun telah menjadi negara sendiri, terdapat beberapa kesamaan antara Indonesia dan Timor Leste, seperti kesamaan suku, bahasa, dan budaya. Kondisi ini terlihat jelas di Kabupaten Malaka yang menjadi wilayah perbatasan langsung dengan Timor Leste. Masyarakat perbatasan yang berada di Kabupaten Malaka terdiri atas dua kelompok masyarakat. Pertama, kelompok masyarakat asli yang memang sejak awal telah menetap di wilayah ini dan kedua, kelompok masyarakat dari Timor Leste yang memilih bergabung ke dalam Negara Kesatuan Republik Indonesia. Di Kabupaten Malaka sendiri terdapat sekitar enam bahasa daerah, yaitu 1) bahasa Tetun Porto, 2) bahasa Tetun Terik, 3) bahasa Bunak, 4) bahasa Dawan, 5) bahasa Mambae, dan 6) bahasa Kemak.

Selain beberapa bahasa daerah tersebut, bahasa Indonesia dan bahasa asing serta bahasa negara tetangga juga mewarnai situasi kebahasaan di wilayah perbatasan RI dengan Timor Leste. Adanya kontak budaya oleh masyarakat yang menetap di wilayah perbatasan tentunya menyebabkan terjadinya kontak bahasa yang memungkinkan mereka untuk memilih bahasa dalam berkomunikasi. Kontak bahasa tersebut tidak hanya terjadi antara masyarakat lokal dan pendatang yang berasal dari dalam negeri, tetapi juga antara masyarakat lokal dan masyarakat yang berasal dari negara tetangga.

Kondisi masyarakat yang multietnis dan multibahasa serta sikap bahasa masyarakat perbatasan telah banyak dibahas dalam beberapa penelitian sebelumnya. Mukhamdanah melakukan penelitian sikap bahasa di wilayah perbatasan Entikong dan Malaysia. Penelitian tersebut memperoleh hasil bahwa pandangan dan sikap bahasa responden terhadap bahasa Indonesia dan bahasa daerah cenderung berada pada kategori positif sementara terhadap bahasa asing cenderung cukup positif. Semakin tinggi tingkat pendidikan responden, semakin tidak positif sikap bahasanya terhadap bahasa asing (Mukhamdanah, 2015). Selanjutnya, Kurniawati juga meneliti tentang sikap bahasa penutur aparat pemerintah terhadap bahasa Retta di Alor. Penelitian ini memperlihatkan bahwa penutur bahasa Retta memiliki sikap positif terhadap bahasa ibunya karena melakukan transmisi bahasa ibu antargenerasi dan 
menggunakannya dalam kehidupan sehari-hari. Sementara itu, aparat pemerintah memiliki sikap positif terhadap bahasa Retta karena bahasa Retta dianggap sebagai bahasa leluhur yang lebih bertahan hidup dan dipelajari untuk mempererat hubungan kekeluargaan (Kurniawati, 2016).

Penelitian ini dilatarbelakangi oleh situasi kebahasaan yang kompleks karena adanya kesamaan bahasa yang digunakan di wilayah perbatasan Malaka dengan Timor Leste. Sebagian masyarakat di perbatasan Malaka berbahasa Tetun. Sementara itu, bahasa Tetun menjadi bahasa resmi di Timor Leste. Adapun beberapa masalah yang dikemukakan dalam tulisan ini adalah 1) bagaimana pilihan bahasa masyarakat di wilayah perbatasan RI-Timor Leste dan 2) bagaimana sikap masyarakat perbatasan terhadap bahasa Indonesia, bahasa daerah, bahasa asing, serta bahasa negara tetangga. Kajian penggunaan, sikap, dan pilihan bahasa oleh masyarakat ini bertujuan untuk mengetahui kecenderungan masyarakat dalam berbahasa di wilayah perbatasan. Selain itu, bahasa yang sering digunakan dapat menjadi salah satu indikator pilihan dan sikap bahasa masyarakat di wilayah perbatasan RI-Timor Leste.

\section{LANDASAN TEORI}

Seorang yang multibahasa memiliki derajat kompetensi bahasa yang berbeda-beda. Perbedaan kompetensi bahasa itu bermacam-macam, mungkin berkisar beberapa item leksikal dan ekspresi, misalnya, penggunaan salam dan perbedaan keterampilan berkomunikasi-dari yang belum sempurna hingga menjadi sangat mahir. Tingkat kompetensi dalam suatu kode dikembangkan berdasarkan kebutuhan pembicara untuk menggunakan bahasa dalam ranah atau untuk aktivitas tertentu. Pembicara menyadari bahwa konteks tidak menentukan pilihan bahasa, tetapi hanya memengaruhinya. Selain itu, pembicara mengacu pada norma dan makna sosial yang dimiliki bersama dalam komunitas, tetapi tidak dikendalikan oleh komunitas tersebut. Penutur juga akan lebih banyak menggunakan bahasa yang lebih dikuasainya (Wardhaugh, 2015).

Sikap merupakan konsep yang tidak mudah untuk didefinisikan. Sikap bahasa adalah kepercayaan, penilaian, dan pandangan terhadap bahasa, penutur atau masyarakatnya serta kecenderungan untuk berperilaku terhadap bahasa, penutur bahasa atau masyarakatnya di dalam cara-cara tertentu (Siregar, 1998). Sikap terdiri atas tiga komponen, yaitu komponen kognitif, afektif, dan konatif. Komponen kognitif berhubungan dengan pengetahuan dan gagasan yang digunakan dalam proses berpikir; komponen afektif menyangkut masalah 
penilaian suka atau tidak suka terhadap sesuatu; dan komponen konatif menyangkut perilaku atau perbuatan sebagai putusan akhir. Melalui komponen tersebut orang mencoba menduga bagaimana sikap seseorang terhadap keadaan yang dihadapinya (Lambert, 1967). Sementara itu, Garret menyebutkan tiga komponen sikap, yaitu aspek kognitif, afektif, dan behavioral. Aspek kognitif dilihat dari sikap yang mengandung keyakinan tentang dunia dan hubungan antara objek-objek signifikansi sosial. Aspek afektif melibatkan perasaan terhadap objek sikap, sedangkan aspek behavioral melibatkan predisposisi untuk bertindak (Garret, 2010).

Selain itu, ada dua pandangan mengenai sikap bahasa, yaitu pandangan behavioris dan pandangan mentalis. Menurut behavioris, sikap terhadap bahasa merupakan kesatuan konsep yang dipahami dengan mengobservasi sikap dan respons terhadap pemakaian bahasa pada situasi sosial yang beragam. Sementara itu, mentalis menganggap sikap tidak hanya berkaitan dengan perilaku yang dapat diamati, tetapi juga keadaan mental yang lebih kompleks dan mendalam yang dimiliki seseorang terhadap bahasa di sekitarnya (Ernanda, 2018).

Pembicaraan mengenai sikap bahasa sering dihubungkan dengan pilihan bahasa karena pilihan bahasa seorang penutur dapat dipengaruhi oleh sikapnya terhadap bahasa itu. Ketika penutur memiliki sikap positif terhadap suatu bahasa, ia akan memilih bahasa tersebut pada sebagian besar interaksi. Sebaliknya, jika penutur memiliki sikap negatif terhadap bahasanya, akan berkembang resistensi dalam penggunaan bahasanya itu. Pilihan bahasa dapat dipandang sebagai memilih beberapa bahasa dalam suatu hubungan kompetitif. Artinya, salah satu dari beberapa bahasa dipilih sebagai media komunikasi. Pilihan bahasa dalam arti yang lebih dinamis berkaitan dengan pertanyaan tentang bahasa atau bahasa-bahasa mana yang dapat digunakan pada situasi tertentu untuk mencapai tujuan yang interaksional, komunikatif, atau kognitif. Dalam hal ini, pilihan dapat berupa satu bahasa atau beberapa bahasa dari sekian bahasa yang ada di suatu masyarakat (Haberland, 2013).

Pilihan bahasa juga didorong oleh berbagai faktor, seperti status sosial, gender, tingkat pendidikan, etnisitas, usia, pekerjaan, tempat tinggal (pedesaan atau perkotaan), penutur, topik pembicaraan, tempat, media, dan formalitas situasi. Selain itu, bahasa dominan juga dapat memengaruhi pilihan bahasa seorang penutur. Sebagian besar penutur yang bilingual atau multilingual—kemungkinan—memilih bahasa yang dominan sebagai media komunikasi karena bahasa itu memberikan mereka keuntungan yang lebih besar, manfaat ekonomi, perluasan jaringan sosial, dan kesempatan yang lebih baik (Qawar \& A., 2015). 


\section{METODE PENELITIAN}

Penelitian ini menggunakan metode penelitian kuantitatif dan kualitatif. Data dalam penelitian ini adalah data primer yang diambil melalui instrumen. Instrumen yang digunakan adalah kuesioner yang terdiri atas 99 butir pertanyaan. Pertanyaan dalam kuesioner tersebut terdiri atas pertanyaan mengenai penggunaan dan sikap bahasa masyarakat terhadap bahasa daerah, bahasa Indonesia, bahasa asing, dan bahasa negara tetangga. Bahasa asing yang dimaksud dalam penelitian ini adalah bahasa selain bahasa daerah dan Indonesia, sedangkan bahasa negara tetangga dalam tulisan ini adalah bahasa asing selain bahasa daerah dan bahasa Indonesia yang digunakan di negara Timor Leste.

Selain kuesioner, data dalam penelitian ini juga diperoleh dari pengamatan partisipatif. Data tersebut digunakan untuk melengkapi data primer. Adapun responden yang terlibat dalam pengisian kuesioner pada penelitian ini berjumlah 108 orang dengan karakteristik sosial berupa jenis kelamin, usia, dan tingkat pendidikan. Kategori responden dari segi usia dibagi dalam tiga kelompok usia, yaitu responden yang berusia di bawah 25 tahun, rentang usia 2550 tahun, dan responden yang berusia di atas 50 tahun. Pada tingkat pendidikan, responden dikategorikan dalam tiga kelompok tingkat pendidikan, yaitu tingkat pendidikan rendah, menengah, dan tinggi.

Pengolahan dan analisis data dalam penelitian ini dilakukan melalui tabulasi data dan penghitungan indeks. Tabulasi jawaban responden diolah dengan menggunakan skala Likert dan dianalisis melalui program SPSS. Sementara itu, indeks dihitung dengan menjumlahkan skor jawaban responden pada tiap kelompok pertanyaan serta membaginya dengan pertanyaan yang dijumlahkan dan skor tertinggi jawaban.

$$
\text { Indeks }=\frac{\left(X_{1}+X_{2}+X_{3}+\ldots\right)}{N}: 5
$$

Keterangan

$\mathrm{X}_{1,2,3}$ : butir soal

$\mathrm{N} \quad$ : banyak soal yang dijumlah

Selanjutnya, hasil analisis dibagi dalam lima kategori mengenai penggunaan bahasa dan lima kategori mengenai sikap bahasa seperti berikut.

\begin{tabular}{cll}
\hline \multicolumn{1}{c}{ Indeks } & Kategori Penggunaan Bahasa & Kategori Sikap Bahasa \\
\hline $0,00-0,20$ & Sangat pasif & Sangat negatif \\
$0,21-0,40$ & Pasif & Negatif \\
$0,41-0,60$ & Kurang aktif & Kurang positif \\
$0,61-0,80$ & Aktif & Positif \\
$0,81-1,00$ & Sangat aktif & Sangat positif \\
\hline
\end{tabular}


Penelitian terhadap pilihan dan sikap bahasa masyarakat perbatasan ini dilakukan di Desa Alas Selatan, Kecamatan Kobalima Timur, Kabupaten Malaka, Provinsi Nusa Tenggara Timur. Kecamatan Kobalima Timur adalah kecamatan paling timur yang berbatasan langsung dengan Distrik Cova-Lima, Timor Leste. Desa Alas Selatan yang berpusat di Lalebun merupakan daerah pantai dengan wilayah seluas $30,60 \mathrm{~km}^{2}$. Desa ini berjarak $\pm 7 \mathrm{~km}$ dari kecamatan dan $\pm 26 \mathrm{~km}$ dari kabupaten. Berdasarkan data Badan Pusat Statistik tahun 2018, Desa Alas Selatan terdiri atas 773 kepala keluarga yang tersebar di 12 dusun dengan 7 rukun warga dan 21 rukun tangga. ${ }^{1}$

\section{PEMBAHASAN}

Masyarakat perbatasan di Desa Alas Selatan, Malaka terdiri atas beberapa penutur dari berbagai bahasa daerah, bahasa Indonesia, dan bahasa asing. Selain itu, masyarakat perbatasan ini juga berhadapan dengan penutur bahasa negara tetangga yang menggunakan bahasa Tetun, bahasa resmi di Timor Leste. Tulisan ini mengaitkan hasil analisis data pada penggunaan bahasa dengan pilihan bahasa oleh masyarakat. Penggunaan bahasa yang berada pada kategori sangat aktif dan aktif menunjukkan bahwa bahasa tersebut "dipilih" oleh penutur. Sebaliknya, jika penggunaan bahasa oleh penutur berada pada kategori pasif dan sangat pasif, hal tersebut menandakan bahwa penutur cenderung "tidak memilih" bahasa tersebut. Artinya, pilihan pada bahasa tersebut rendah atau tidak dipilih. Pembahasan dalam tulisan ini terdiri atas pilihan bahasa dan sikap bahasa berdasarkan jenis kelamin, usia, dan tingkat pendidikan.

\section{Pilihan Bahasa}

Pilihan bahasa muncul karena adanya banyak bahasa di suatu komunitas masyarakat. Jika ada orang menguasai satu atau beberapa bahasa, ia harus memilih salah satu bahasa untuk berkomunikasi dengan orang lain (Kholidah, 2015). Pilihan bahasa penutur dipengaruhi oleh beberapa faktor, antara lain jenis kelamin, usia, dan tingkat pendidikan (Calvert, 2005). Pilihan bahasa yang dibahas pada subbab ini adalah pilihan bahasa masyarakat terhadap bahasa Indonesia, bahasa daerah, dan bahasa asing.

Berdasarkan jenis kelamin, responden pada penelitian ini terdiri atas 55 responden lakilaki dan 53 responden perempuan. Dalam penggunaan bahasa Indonesia, tidak ada perbedaan

\footnotetext{
${ }^{1}$ Kecamatan Kobalima Timur dalam Angka 2019
} 
antara responden laki-laki dan perempuan. Sebanyak 108 responden, baik responden laki-laki maupun responden perempuan, menyatakan bahwa bahasa Indonesia menjadi bahasa yang dapat digunakan ke mana saja ketika responden bepergian. Oleh karena itu, bahasa Indonesia menjadi bahasa pilihan yang aktif digunakan oleh responden dengan nilai indeks 0,77.

Dalam hal penggunaan bahasa daerah, hasil analisis data menunjukkan bahwa bahasa daerah menjadi bahasa pilihan kedua yang aktif digunakan dengan nilai indeks 0,74 . Tidak ada perbedaan nilai yang signifikan dalam penggunaan bahasa daerah pada responden lakilaki dan perempuan. Namun, penggunaan bahasa daerah pada responden laki-laki (nilai indeks 0,742) cenderung lebih rendah daripada responden perempuan (nilai indeks 0,743). Bagi responden perempuan, bahasa daerah sering digunakan di rumah karena responden perempuan lebih sering berada di rumah. Berikut ini adalah grafik nilai indeks pilihan bahasa berdasarkan jenis kelamin responden.

Grafik 1.

Pilihan Bahasa Berdasarkan Jenis Kelamin

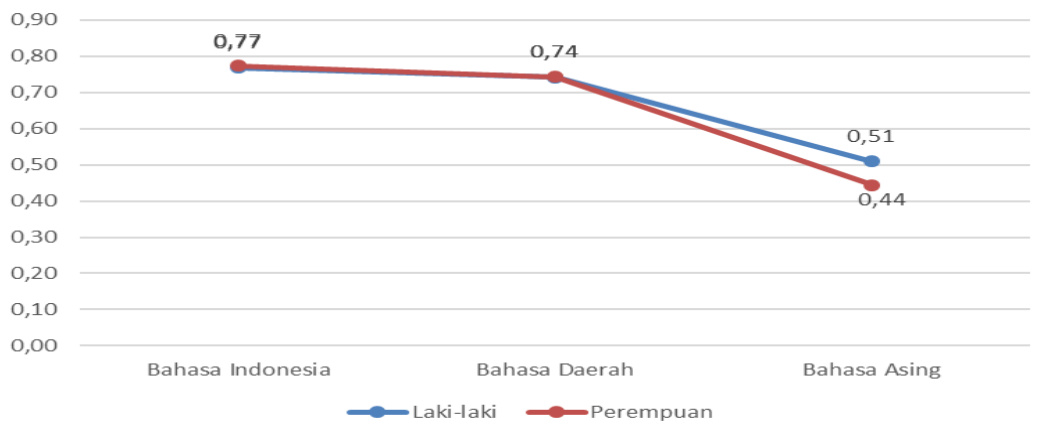

Sebaliknya, penggunaan bahasa asing oleh responden perempuan menunjukkan nilai yang lebih rendah dibandingkan dengan responden laki-laki. Artinya, bahasa asing lebih tidak dipilih oleh responden perempuan. Namun, bagi responden perempuan dan laki-laki bahasa asing menjadi bahasa yang kurang aktif digunakan dengan nilai indeks 0,44 bagi responden perempuan dan 0,51 bagi responden laki-laki. Hal ini berkaitan dengan kegiatan responden perempuan yang lebih sering di rumah dibandingkan dengan responden laki-laki. Responden laki-laki cenderung memiliki mobilitas yang tinggi sehingga kecenderungan mengenal dan memilih bahasa asing lebih tinggi.

Sementara itu, berdasarkan kelompok usia, responden dalam penelitian ini dikategorikan dalam tiga kelompok usia, yaitu di bawah 25 tahun, 25-50 tahun, dan di atas 50 tahun. Responden yang berusia di bawah 25 tahun sebanyak 37 orang, responden yang berada pada rentang usia $25-50$ tahun berjumlah 41 orang, dan responden yang berusia di atas 50 tahun sebanyak 30 orang. Nilai indeks penggunaan bahasa Indonesia oleh responden 
yang berusia di bawah 25 tahun menunjukkan nilai yang lebih tinggi dibandingkan dengan responden yang berusia 25 hingga 50 tahun ke atas, yaitu 0,86. Hal ini menandakan bahwa bahasa Indonesia lebih dipilih dan sangat aktif digunakan oleh responden yang berusia di bawah 25 tahun dalam komunikasi sehari-hari karena usia di bawah 25 tahun merupakan usia sekolah. Bahasa Indonesia menjadi bahasa pengantar pendidikan di sekolah sehingga kecenderungan responden usia ini menggunakan bahasa Indonesia lebih tinggi.

Pada kelompok responden berusia 25-50 tahun, nilai indeks pilihan terhadap bahasa Indonesia berada pada angka 0,77 . Hal tersebut menandakan bahwa bahasa Indonesia aktif digunakan. Sementara itu, nilai indeks pada responden berusia di atas 50 tahun menunjukkan angka 0,66 yang juga menandakan bahwa bahasa Indonesia masih aktif digunakan, tetapi tidak seaktif responden yang berusia 25-50 tahun. Dengan demikian, responden yang berusia di bawah 25 tahun lebih memilih untuk menggunakan bahasa Indonesia dibandingkan dengan responden pada kategori usia lainnya.

Hal yang berbeda terlihat pada penggunaan bahasa daerah oleh responden yang berusia di atas 50 tahun. Responden dengan usia 50 tahun cenderung lebih memilih bahasa daerah untuk digunakan daripada bahasa Indonesia. Nilai indeks bahasa daerah $(0,73)$ pada responden yang berusia di atas 50 tahun lebih tinggi daripada bahasa Indonesia $(0,66)$. Artinya, bagi responden berusia di atas 50 tahun, bahasa daerah merupakan bahasa yang paling dipilih oleh mereka karena responden pada usia ini hanya bergaul dengan orang yang berada di daerah. Responden dengan usia di atas 50 tahun juga memiliki tingkat pendidikan dan mobilitas yang rendah serta kemampuan bahasa daerah yang lebih baik daripada bahasa Indonesia dan bahasa asing. Kemampuan dalam berbahasa daerah yang lebih baik ini menjadi faktor bahasa daerah dipilih oleh responden yang berusia di atas 50 tahun. Selain itu, bahasa daerah lebih dipilih oleh orang yang lebih dewasa untuk menunjukkan rasa kepemilikannya terhadap suatu daerah.

Bahasa yang kurang aktif digunakan berdasarkan usia responden adalah bahasa asing. Penggunaan bahasa asing oleh responden dari segi usia menunjukkan indeks angka yang lebih rendah dibandingkan dengan bahasa Indonesia dan bahasa daerah. Penggunaan bahasa asing oleh responden yang berusia di bawah 25 tahun dan 25-50 tahun berada pada nilai indeks yang lebih tinggi, yaitu 0,58 dan 0,45 dibandingkan dengan kelompok usia responden di atas 50 tahun. Responden yang berusia 50 tahun ke bawah berada pada kategori penggunaan bahasa asing yang kurang aktif dan responden yang berusia di atas 50 tahun menunjukkan penggunaan bahasa asing yang berada pada kategori pasif dengan nilai indeks 0,39. Hal 
tersebut menandakan bahwa bahasa asing oleh responden berdasarkan tiga kelompok usia tersebut kurang dipilih oleh masyarakat dibandingkan dengan bahasa daerah dan bahasa Indonesia. Adapun hasil analisis pada penggunaan dan pilihan bahasa responden berdasarkan usia dapat dilihat pada grafik berikut.

Grafik 2.

Pilihan Bahasa Berdasarkan Usia

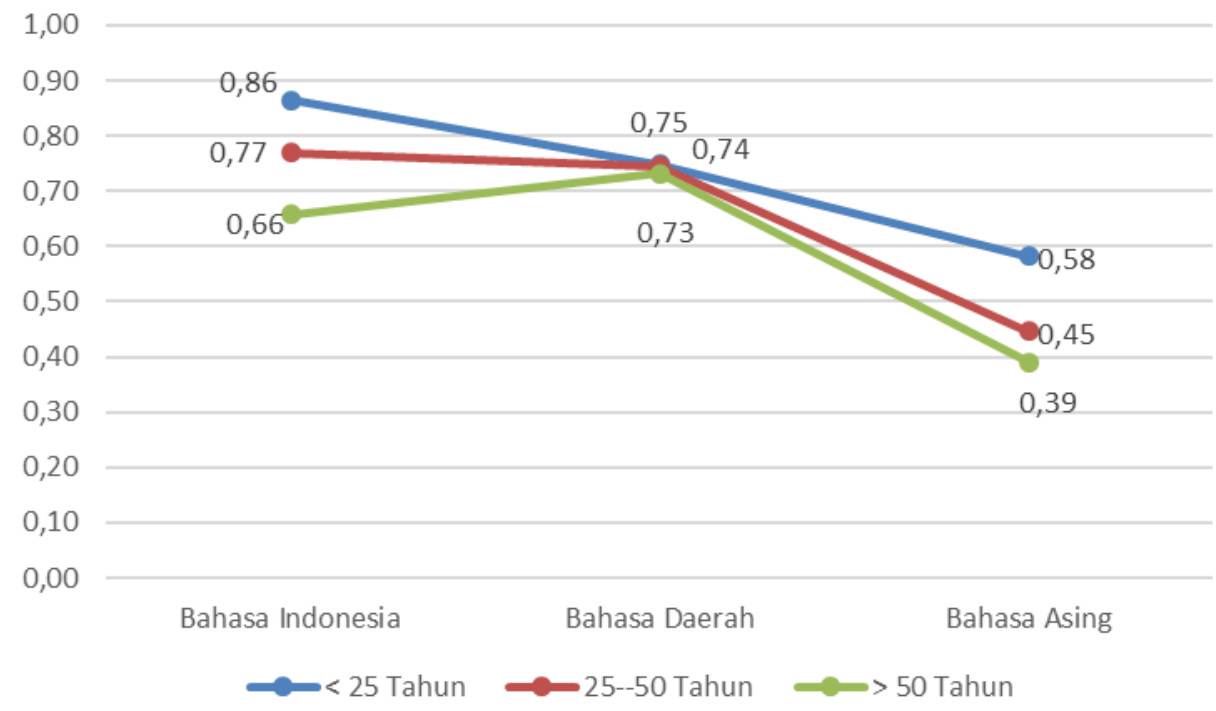

Pada tingkat pendidikan, bahasa Indonesia menjadi bahasa pilihan pertama bagi kelompok responden berlatar pendidikan rendah, menengah, dan tinggi. Bahasa Indonesia sangat aktif digunakan oleh responden yang berlatar pendidikan tingkat menengah dengan nilai indeks 0,84 , sedangkan responden yang berlatar pendidikan dasar/rendah dan tinggi menggunakan bahasa Indonesia hanya secara aktif. Sangat aktifnya penggunaan bahasa Indonesia oleh responden dengan tingkat pendidikan menengah tersebut sejalan dengan penggunaan bahasa Indonesia berdasarkan usia. Pada hasil analisis data penggunaan bahasa berdasarkan usia, responden yang berusia di bawah 25 tahun lebih memilih bahasa Indonesia karena sebagian besar responden pada usia itu sedang menempuh pendidikan pada tingkat pendidikan menengah sehingga mereka lebih sering menggunakan bahasa Indonesia di dunia pendidikan.

Pilihan bahasa yang berbeda terlihat pada responden yang berpendidikan rendah. Bahasa daerah oleh responden dengan tingkat pendidikan rendah berada pada kategori yang lebih aktif digunakan daripada bahasa Indonesia. Hal ini terjadi karena sebagian besar responden dengan tingkat pendidikan rendah adalah responden usia dewasa dan generasi lanjut usia. Sesuai dengan hasil analisis pada penggunaan bahasa daerah berdasarkan usia, responden dengan usia di atas 50 tahun ini cenderung lebih memilih bahasa daerah sehingga 
nilai indeks penggunaan bahasa daerah lebih tinggi dibandingkan dengan bahasa lain seperti terlihat pada grafik berikut.

Grafik 3.

Pilihan Bahasa Berdasarkan Tingkat Pendidikan

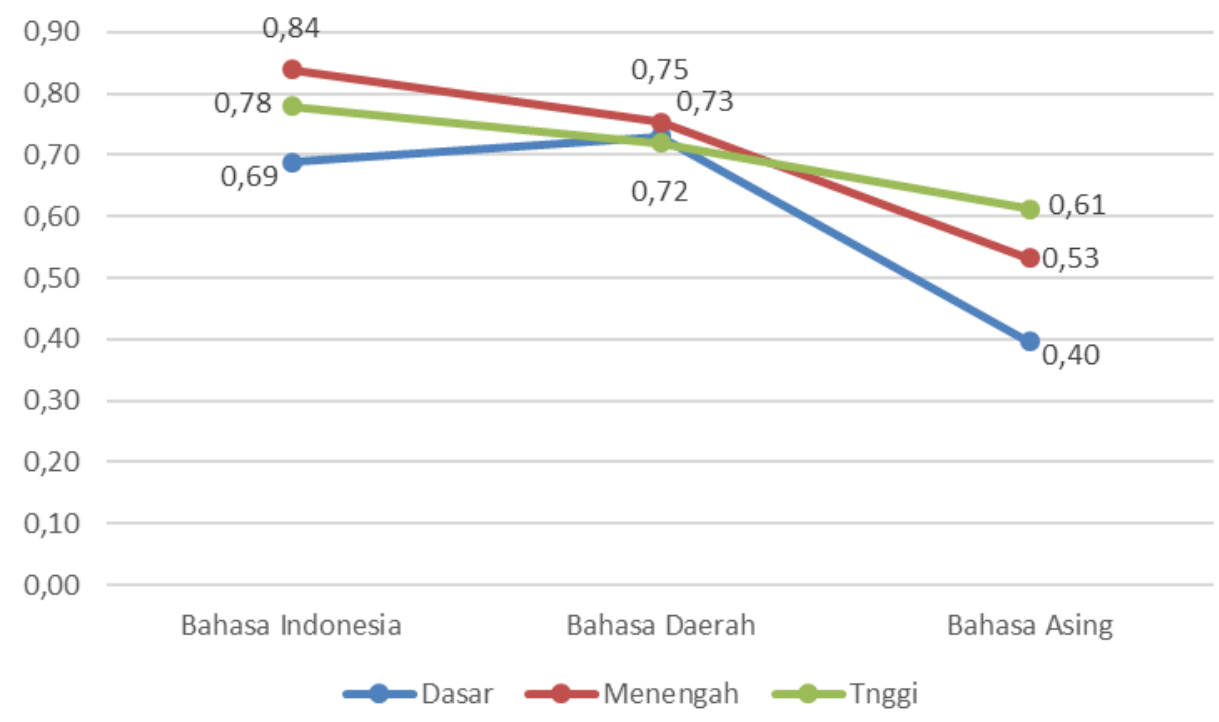

Grafik di atas menunjukkan bahwa responden dengan tingkat pendidikan rendah, menengah, dan tinggi lebih memilih menggunakan bahasa Indonesia dengan kategori aktif dan sangat aktif. Sementara itu, bahasa asing menjadi bahasa yang digunakan secara kurang aktif. Namun, nilai indeks penggunaan bahasa asing oleh responden berpendidikan tinggi menunjukkan kategori aktif digunakan. Artinya, bahasa asing bagi responden dengan pendidikan tinggi termasuk bahasa yang juga dipilih, selain bahasa daerah dan bahasa Indonesia. Hal ini dipengaruhi oleh anggapan bahwa menggunakan bahasa asing membuat seseorang terlihat hebat, sedangkan menggunakan bahasa daerah terkesan biasa saja. Bagi responden berpendidikan tinggi, bahasa asing menjadi bahasa yang dipilih karena kegunaannya untuk berkomunikasi dengan penutur dari luar negara. Responden dengan pendidikan tinggi juga menggunakan bahasa asing untuk menunjukkan strata sosial yang tinggi.

Nilai indeks keseluruhan terhadap bahasa yang digunakan dan dipilih oleh responden masyarakat perbatasan RI dan Timor Leste berdasarkan jenis kelamin, usia, dan tingkat pendidikan dapat dilihat pada tabel berikut.

Tabel 1.

Indeks dan Kategori Penggunaan Bahasa

\begin{tabular}{lll}
\hline \multicolumn{1}{c}{ Bahasa } & Indeks & \multicolumn{1}{c}{ Kategori Penggunaan } \\
\hline Bahasa Indonesia & 0,77 & Aktif \\
\hline Bahasa daerah & 0,74 & Aktif \\
\hline Bahasa asing & 0,47 & Kurang aktif
\end{tabular}


Berdasarkan nilai indeks tersebut, bahasa yang aktif digunakan oleh masyarakat adalah bahasa Indonesia dan daerah. Dengan demikian, bahasa Indonesia dan daerah menjadi bahasa yang dipilih oleh masyarakat perbatasan RI-Timor Leste. Bahasa Indonesia dipilih untuk digunakan dalam berkomunikasi dengan penutur yang berbahasa daerah lain karena hubungan etnis yang berbeda, sedangkan bahasa daerah hanya digunakan oleh penutur bahasa se-etnis. Sementara itu, bahasa asing bagi sebagian besar masyarakat perbatasan RI-Timor Leste menjadi bahasa yang kurang dipilih karena kecenderungan masyarakat perbatasan yang tidak aktif berkomunikasi dengan penutur bahasa selain bahasa Indonesia dan daerah.

\section{Sikap Bahasa Masyarakat}

Sikap mengacu pada pandangan atau respons seseorang terhadap suatu hal. Biasanya sikap ditunjukkan melalui perasaan "senang" atau "tidak senang, "suka" atau "tidak suka". Sikap bahasa adalah posisi mental atau perasaan terhadap bahasa sendiri atau bahasa orang lain (Kridalaksana, 1985). Dalam pembahasan ini, sikap bahasa masyarakat perbatasan dikategorikan ke dalam sikap "positif" atau "negatif” dengan mengaitkannya dengan jenis kelamin, usia, dan tingkat pendidikan responden.

Seperti yang telah disebutkan pada uraian sebelumnya, situasi kebahasaan masyarakat perbatasan RI-Timor Leste diwarnai oleh bahasa daerah, bahasa Indonesia, dan bahasa asing. Selain itu, terdapat pula bahasa negara Timor Leste sehingga sikap bahasa masyarakat perbatasan RI-Timor Leste yang dibahas tidak hanya sikap bahasa terhadap bahasa daerah, bahasa Indonesia, dan bahasa asing saja, tetapi juga bahasa negara tetangga. Tujuannya adalah untuk mengetahui bagaimana pandangan masyarakat di perbatasan terhadap bahasa negara tetangga, yaitu bahasa Tetun.

Berdasarkan jenis kelamin, sikap bahasa responden laki-laki terhadap bahasa daerah menunjukkan sikap yang lebih positif $(0,68)$ jika dibandingkan dengan responden perempuan $(0,65)$. Demikian pula dengan sikap bahasa responden laki-laki terhadap bahasa negara tetangga yang menunjukkan nilai indeks yang lebih positif dibandingkan dengan responden perempuan. Namun, sikap bahasa responden laki-laki dan perempuan terhadap bahasa Indonesia menunjukkan sikap yang sangat positif $(0,82)$. Ini menandakan bahwa bahasa Indonesia masih menjadi bahasa yang dibanggakan. Menurut pengakuan responden, mereka dapat berkomunikasi dengan siapa saja dengan menggunakan bahasa Indonesia. Perbedaan etnis dan bahasa tidak menyebabkan masyarakat di wilayah perbatasan ini tidak saling berkomunikasi. Dengan bahasa Indonesia, masyarakat dapat berinteraksi secara luas tanpa 
batas suku, baik bagi responden laki-laki maupun responden perempuan. Gambaran sikap bahasa masyarakat terhadap bahasa Indonesia, bahasa daerah, bahasa asing, dan bahasa negara tetangga berdasarkan jenis kelamin dapat dilihat pada grafik berikut.

Grafik 4.

Sikap Bahasa Masyarakat Berdasarkan Jenis Kelamin

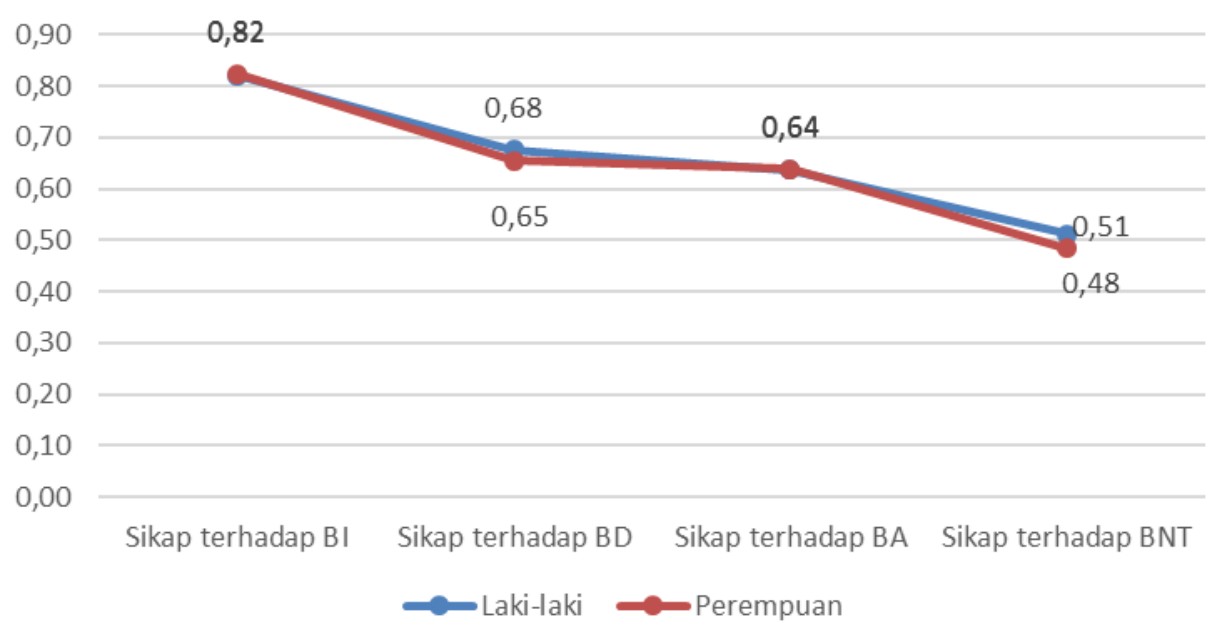

Berdasarkan usia, sikap bahasa yang sangat positif terhadap bahasa Indonesia ditunjukkan oleh responden yang berusia di bawah 50 tahun. Sementara itu, sikap bahasa responden yang berusia di bawah 25 tahun terhadap bahasa asing lebih positif dibandingkan dengan bahasa daerahnya. Responden usia ini memiliki pandangan bahwa bahasa asing merupakan bahasa yang lebih memberikan manfaat untuk memperluas pergaulan dan mempermudah responden dalam menambah informasi dan pengetahuan. Demikian pula sikap responden yang berusia di bawah 25 tahun terhadap bahasa negara tetangga. Di antara tiga kelompok responden, responden berusia di bawah 25 tahun menunjukkan sikap bahasa yang lebih tinggi (nilai indeks 0,52) daripada sikap bahasa responden yang berusia di atas 25 tahun $(0,48$ dan 0,49$)$ terhadap bahasa negara tetangga. Namun, ketiga kelompok responden berdasarkan usia ini sama-sama menunjukkan sikap bahasa yang kurang positif terhadap bahasa negara tetangga. Pandangan yang positif terlihat pada sikap bahasa responden terhadap bahasa Indonesia seperti grafik berikut. 
Grafik 5.

Sikap Bahasa Masyarakat Berdasarkan Usia

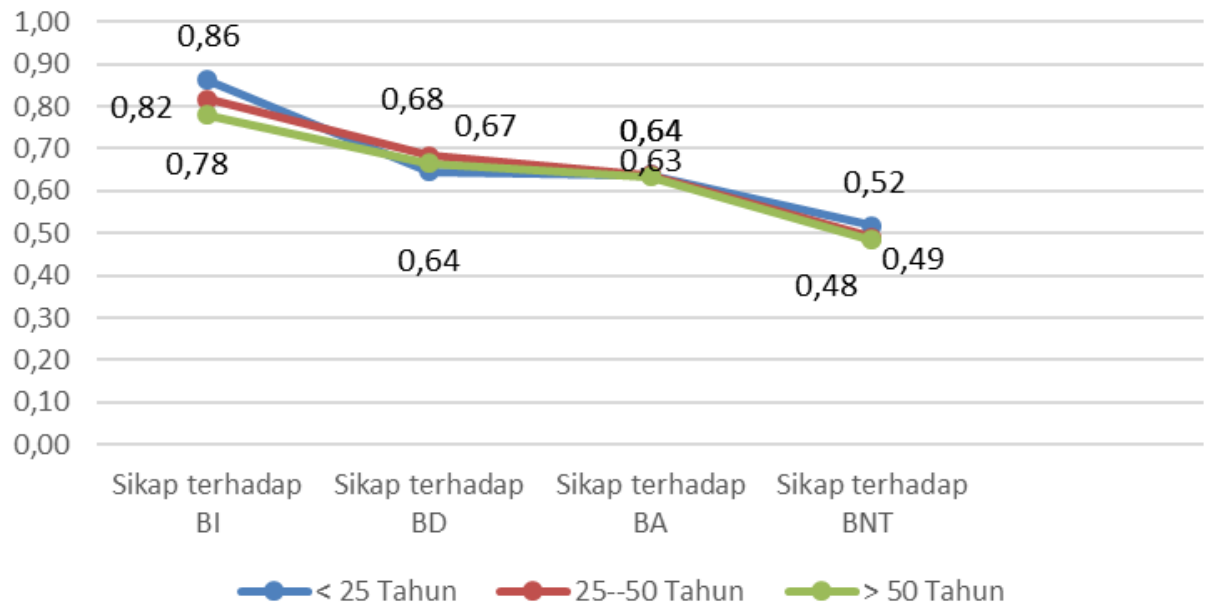

Selanjutnya adalah sikap bahasa responden terhadap bahasa Indonesia, bahasa daerah, bahasa asing, dan bahasa negara tetangga berdasarkan tingkat pendidikan. Responden dengan tingkat pendidikan dasar/rendah menunjukkan sikap yang positif terhadap bahasa Indonesia dengan nilai indeks 0,79 ; bahasa daerah dengan nilai indeks 0,67 ; dan bahasa asing dengan nilai indeks 0,64 . Sementara itu, sikap yang kurang positif terhadap bahasa negara tetangga ditunjukkan oleh responden dengan tingkat pendidikan dasar dengan nilai indeks 0,47 . Seperti responden dengan tingkat pendidikan dasar, responden dengan tingkat pendidikan menengah juga memperlihatkan sikap yang positif terhadap bahasa daerah $(0,66)$ dan bahasa asing $(0,64)$, sedangkan sikap terhadap bahasa Indonesia adalah sangat positif $(0,85)$. Responden dengan tingkat pendidikan menengah ini menjadi responden dengan nilai indeks sikap terhadap bahasa Indonesia yang paling tinggi dibandingkan dengan responden dengan tingkat pendidikan dasar dan tinggi. Berikut adalah grafik yang menggambarkan sikap bahasa masyarakat berdasarkan tingkat pendidikan.

Grafik 6.

Sikap Bahasa Masyarakat Berdasarkan Tingkat Pendidikan

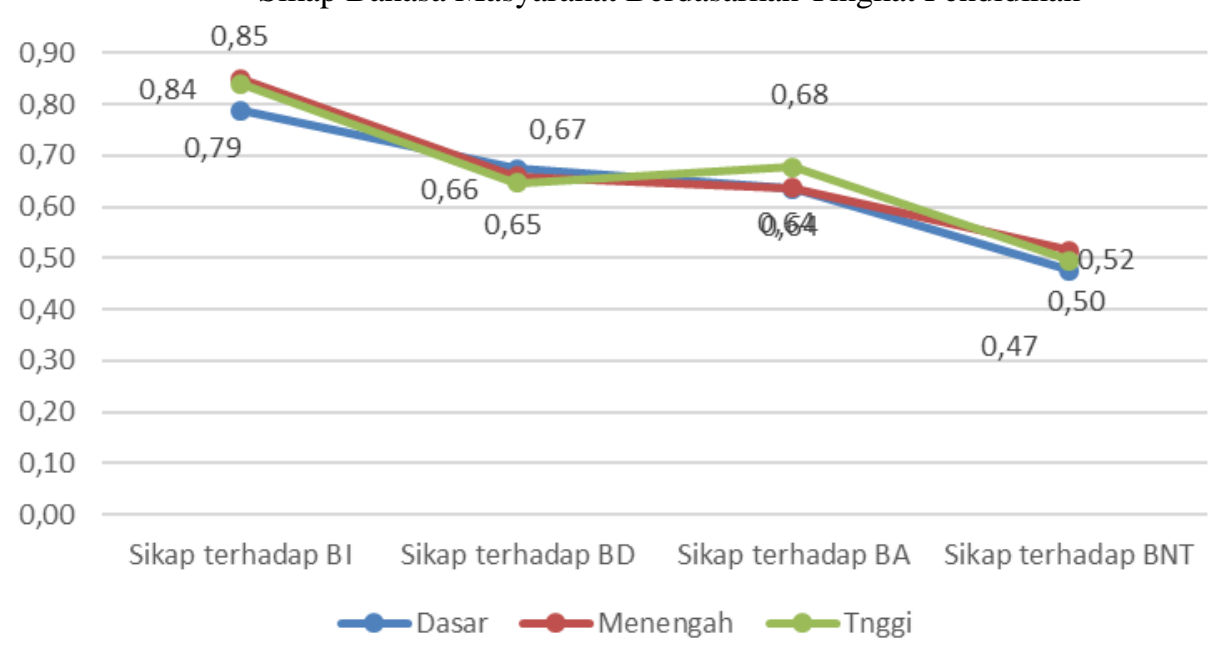

(C)2020, Ranah: Jurnal Kajian Bahasa, 9(2), 
Hal yang terlihat berbeda adalah sikap bahasa responden dengan tingkat pendidikan tinggi terhadap bahasa asing yang lebih positif daripada bahasa daerah. Menurut responden dengan tingkat pendidikan tinggi, bahasa daerah tidak perlu digunakan sebagai bahasa pengantar di sekolah. Mereka beranggapan bahwa bahasa asing yang sebaiknya menjadi bahasa pengantar dan perlu dipelajari di sekolah agar anak-anak dapat berbahasa asing. Dengan mempelajari bahasa asing, banyak manfaat yang dapat diperoleh. Bahasa asing dianggap dapat mempercepat upaya pencerdasan bangsa, memudahkan untuk memperoleh informasi dan pengetahuan, memudahkan mencari pekerjaan, dan dapat memperluas pergaulan.

Secara keseluruhan, nilai indeks dan kategori sikap bahasa oleh masyarakat perbatasan RI dengan Timor Leste berdasarkan jenis kelamin, usia, dan tingkat pendidikan tercantum pada tabel berikut.

Tabel 2.

Indeks dan Kategori Sikap Bahasa

\begin{tabular}{lcl}
\hline \multicolumn{1}{c}{ Bahasa } & Indeks & \multicolumn{1}{c}{ Kategori Sikap } \\
\hline Bahasa Indonesia & 0,82 & Sangat positif \\
\hline Bahasa daerah & 0,67 & Positif \\
\hline Bahasa asing & 0,63 & Positif \\
\hline Bahasa negara tetangga & 0,50 & Kurang positif \\
\hline
\end{tabular}

Dari indeks dan kategori pada tabel tersebut, sikap bahasa masyarakat perbatasan berdasarkan jenis kelamin, usia, dan tingkat pendidikan menunjukkan bahwa sikap bahasa masyarakat terhadap bahasa Indonesia berada berada pada kategori sikap yang sangat positif, sikap terhadap bahasa daerah dan bahasa asing berada pada kategori sikap yang positif, serta sikap terhadap bahasa negara tetangga berada pada kategori sikap yang kurang positif. Dengan demikian, masyarakat perbatasan RI dan Timor Leste di Desa Alas Selatan, Kabupaten Malaka masih menganggap bahwa bahasa Indonesia adalah bahasa yang paling diutamakan.

\section{PENUTUP}

Jika dilihat berdasarkan pilihan penggunaan bahasanya, masyarakat Desa Alas Selatan, Kobalima Timur, Kabupaten Malaka cenderung memilih menggunakan bahasa Indonesia dan bahasa daerah, tergantung mitra tutur responden. Masyarakat memilih bahasa Indonesia untuk berkomunikasi dengan penutur bahasa daerah lain, sedangkan bahasa daerah digunakan untuk berkomunikasi dengan penutur bahasa se-etnis. Pilihan terhadap bahasa Indonesia ini selaras dengan sikap bahasa yang ditunjukkan oleh masyarakat perbatasan di wilayah tersebut. 
Masyarakat di Kobalima Timur menunjukkan sikap yang sangat positif terhadap bahasa Indonesia. Selain karena bahasa Indonesia dianggap sebagai bahasa yang paling komunikatif, bahasa Indonesia juga menjadi bahasa yang mampu menjembatani perbedaan bahasa dalam interaksi sosial masyarakat. Sementara itu, sikap bahasa masyarakat terhadap bahasa daerah dan bahasa asing juga memperlihatkan sikap yang positif, sedangkan sikap terhadap bahasa negara tetangga adalah kurang positif. Meskipun sikap bahasa masyarakat terhadap bahasa asing positif, masyarakat Kobalima Timur tidak menggunakan bahasa asing dalam komunikasi. Masyarakat perbatasan RI-Timor Leste hanya memiliki pandangan yang positif terhadap bahasa asing karena manfaat dan kegunaan bahasa asing sebagai bahasa yang jika dikuasai mampu membuat orang itu terlihat lebih cerdas.

\section{DAFTAR PUSTAKA}

Calvert, D. A. H. S. L. (2005). Gender, Identity, and Language Use in Teenage Blogs. Journal of Computer-Mediated Communication, $\quad 10(2) . \quad$ https://doi.org/10.1111/j.10836101.2005.tb00238.x

Ernanda. (2018). Pemilihan Bahasa dan Sikap Bahasa pada Masyarakat Pondok Tinggi Kerinci. Jurnal Ilmu Humaniora, 2(2), 19. http://download.garuda.ristekdikti.go.id/article.php?article=$1104601 \& \mathrm{val}=16609 \&$ title $=$ PEMILIHAN BAHASA DAN SIKAP BAHASA PADA MASYARAKAT PONDOK TINGGI KERINCI

Garret, P. (2010). Attitudes of Language. Cambridge Universty Press. https://doi.org/10.1017/CBO9780511844713

Haberland, H. (2013). Language Alternation, Language Choice and Language Encounter in International Tertiary Education. Springer. https://doi.org/10.1007/978-94-007-6476-7

Kholidah, U. (2015). Pemertahanan Bahasa Jawa pada Interaksi Siswa dan Guru dalam Pembelajaran Kajian Sosiolinguistik di Mts Al-Hikmah Pasir Demak. Ranah: Jurnal Kajian Bahasa, 4(2). https://doi.org/10.26499/rnh.v4i2.27

Kridalaksana, H. (1985). Fungsi bahasa dan sikap bahasa. Nusa Indah.

Kurniawati, W. (2016). Sikap Bahasa Penutur Bahasa Jati dan Aparat Pemerintah Terhadap Bahasa Retta di Alor. Ranah Jurnal Kajian Bahasa, 5(2). https://doi.org/10.26499/rnh.v5i2.152

Lambert, W. E. (1967). A Social Psychology of Bilingualism. Journal Of Social Issues, 23, 18. https://doi.org/10.1111/j.1540-4560.1967.tb00578.x

Mukhamdanah. (2015). Pandangan dan Sikap Bahasa Masyarakat di Wilayah Perbatasan: Kasus Masyarakat di Entikong. Ranah Jurnal Kajian Bahasa, 4(2). https://doi.org/10.26499/rnh.v4i2.32

Qawar, B. S. D., \& A., weik H. (2015). Language Choice and Language Attitudes in a Multilingual Arab Canadian Community: Quebec-Canada: a Sociolinguistic Study. British Journal of English Linguistics, 3(1).

Siregar, B. U. (1998). Pemertahanan Bahasa dan Sikap Bahasa: Kasus Masyarakat Bilingual di Medan. Pusat Pembinaan dan Pengembangan Bahasa. https://labbineka.kemdikbud.go.id/files/upload/bbs_MKTGXNDC_1568711011.pdf

Mangku, Dewa Gede Sudika. (2019). Sejarah dan Fungsi Perbatasan Darat antara Indonesia dan Timor Leste. Tanjungpura Law Journal, 3(1), 1-16. http://dx.doi.org/10.26418/tlj.v3i1.34492

Wardhaugh, R. (2015). An Introduction To Sociolinguistics (Seventh Ed). John Wiley \& Sons, Inc. 